

\title{
INDONESIAN FISHERIES RESEARCH JOURNAL
}

\author{
Editorial Board: \\ Nurzali Naamin \\ Alie Poernomo \\ Johanes Widodo \\ Victor P.H. Nikijuluw \\ Santosa Koesoemadinata \\ Managing Editors: \\ Murniyati \\ Endang Pratiwi \\ Bambang Priono \\ Sri Ismawati \\ Published by: \\ Central Research Institute for Fisheries \\ Manuscripts may be sent to the publisher: \\ Indonesian Fisheries Research Journal \\ Central Research Institute for Fisheries \\ Jalan K.S. Tubun Petamburan VI \\ P.O. Box 6650 Slipi \\ Jakarta 11410A \\ Indonesia \\ Phone: (021) 5709162 \\ Facs.: (021) 5709159
}




\title{
PREFACE
}

Indonesian Fisheries Research Journal is the English edition of research journal published by Central Research Institute for Fisheries (CRIFI). The journal which will be published once a year is meant as an effort to expand communication network between scientists of research institutes under CRIFI with their fellow fisheries scientists in other countries, especially in Asia and Australia.

Articles contained in this journal area reports of research institutes under CRIFI. Articles accepted in this journal may cover a wide range of disciplines related to fisheries resources and technologies, including fishery postharvest as well as fisheries economics.

It is hoped that the Indonesian Fisheries Research Journal will also constribute to the progress of fisheries science and technology in both in country as well as of the region.

We wish to express our sincere thanks to Dr. Nick Willoughby of NRI (Natural Resources Institute) United Kingdom for his valuable corrections, critisms an suggestions of the manuscript of this journal.

Central Research Institute for Fisheries

Director,

\author{
Dr. Fuad Cholik
}




\section{CONTENTS}

PREFACE

The Effect of Salinity, Temperature and Gamete Density on the Embryonic Development of the Slipper Oyster, Crassostrea iredalei Faustino By: Achmad Sudradjat

Structure of Fish Community and Reproductive Biology of Three Indigenous Species of Cyprinids in Kedungombo Reservoir

By: Endi Setiadi Kartamihardja

Biochemical Genetics of Tiger Shrimp Penaeus monodon: Description of Electrophoretic Detectable Loci

By: Ketut Sugama, Haryanti, and Fuad Cholik

Measurements of the Acute Toxicity of Cypermethrin to Nile Tilapia (Oreochromis niloticus), using A Static and A Continuous-Flow System

By: Santosa Koesoemadinata

Growth, Intermoult Period and Weight of Edible Portions of Giant Prawn and Tiger Shrimp

By: Darti Satyani

Export Efficiency of the Fish Processing Industry in North Sulawesi

By: Victor P.H. Nikijuluw, Riyanto Basuki, Daniel R. Monintja, and John Haluan ...

Thiamine in Fish and Its Degradation during Thermal Processing of Salted-Boiled Fish

By: Suparno, S.W. Hanson, and A.J. Rosenthal 